\title{
ANALISIS ORIENTASI KEWIRAUSAHAAN BERBASIS KEARIFAN LOKAL UNTUK MENINGKATKAN KINERJA PEMASARAN PADA PENGRAJIN KEBEN DI BANJAR TANGGAHAN PEKEN DESA SULAHAN KECAMATAN SUSUT KABUPATEN BANGLI
}

\author{
Made Mulia Handayani \\ Nyoman Dwika Ayu Amrita \\ Fakultas Ekonomi Universitas Ngurah Rai - Denpasar e- \\ mail :muliahandayani29@gmail.com
}

\begin{abstract}
Abstrak-Penerapan orientasi kewirausahaan merupakan hal yang penting bagi para pelaku ekonomi. Ketatnya persaingan menuntut pelaku usaha melakukan inovasi yang terusmenerus. Inovasi yang dilakukan tentu saja tidak melupakan nilai-nilai kearifan lokal yang terdapat pada masyarakat setempat. Kondisi ini mengarahkan para pengrajin keben di banjar Tanggahan Peken untuk menerapkan orientasi kewirausahaan berbasis kearifan lokal. Kajiankajian mengenai kearifan lokal banyak dikaitkan dengan nilai-nilai,kebiasaan dan tradisi yang positip dari suatu masyarakat dari sudut pandang sosial,budaya dan lingkungan.Keben sebagai salah satu alat untuk tempat persembahan umat Hindu kepada Tuhan Yang Maha Esa juga biasa di pakai pada acara-acara adat lainnya, sehingga keben memiliki makna yang erat kaitannya dengan pelaksanaan upacara dan adat. Inovasi pada pembuatan dan desain keben sangat perlu dilakukan mengingat kerajinan keben ini merupakan penopang perekonomian rakyat di banjar Tanggahan Peken yang menjadi mayoritas mata pencaharian penduduk di sana. Setiap bentuk keben dan corak yang menghiasinya diambil dari nilai-nilai kearifaan lokal masyarakat setempat. Penelitian ini bertujuan untuk menganalisis orientasi kewirausahaan berbasis kearifan lokal sebagai upaya meningkatkan kinerja pemasaran pengrajin keben di Banjar Tanggahan Peken. Penelitian ini menggunakan metode kualitatif dengan menggunakan instrumen penelitian wawancara, observasi dan juga studi dokumentasi. Hasil analisis data dalam penelitian ini menggunakan deskriptif kualitatif. Hasil Penelitian menjelaskan bahwa 1) perkembangan usaha kerajinan keben di Banjar Tanggahan Peken mengalami pasang surut, dari jumlah pengrajin mengalami penurunan, akan tetapi dari jumlah pengepul mengalami peningkatan. 2) Penerapan orientasi kewirausahaan berbasis kearifan lokal dapat meningkatkan kinerja pemasaran usaha kerajinan keben, hal ini menuntut para pengrajin agar selalu melakukan inovasi, bersikap proaktif dan berani menanggung resiko.
\end{abstract}

\section{Kata Kunci : Orientasi Kewirausahaan, Nilai Kearifan Lokal, Kinerja Pemasaran Pengrajin Keben}

Abstract- The application of entrepreneurial orientation is important for economic actors. The intense competition requires businesses to innovate constantly. The innovation carried out certainly does not forget the values of local wisdom found in the local community. This 


\section{JURNAL CAKRAWATI, Vol. 3 No. 1, Pebruari-Juli 2020 ISSN: 2620-5173}

condition led the keben craftsmen in the Tanggahan Peken banjar to implement an entrepreneurial orientation based on local wisdom. Studies on local wisdom are mostly associated with positive values, habits and traditions of a society from a social, cultural and environmental perspective. Keben as one of the tools for Hindu offerings to God Almighty is also commonly used at other traditional events, so keben has a meaning that is closely related to the implementation of ceremonies and customs. Innovation in the making and design of keben is very necessary considering that the craft of keben is the mainstay of the people's economy in the Banjar Tanggahan Peken which is the majority of the people's livelihoods there. Every form of keben and style that decorates it is taken from the values of the local wisdom of the local community. This study aims to analyze the entrepreneurship orientation based on local wisdom as an effort to improve the marketing performance of keben craftsmen in Banjar Tanggahan Peken. This study uses a qualitative method using interview research instruments, observation and documentation studies. The results of data analysis in this study used descriptive qualitative. The results of the study explained that 1) the development of keben handicraft business in Banjar Tanggahan Peken experienced ups and downs, from the number of craftsmen having decreased, but from the number of collectors experiencing an increase. 2) The application of entrepreneurship orientation based on local wisdom can improve the marketing performance of keben craft business, this requires the craftsmen to always innovate, be proactive and be brave to take risks.

\section{Keywords: Entrepreneurship Orientation Local Wisdom Value Marketing Performance Keben Craftsme}

\section{PENDAHULUAN}

Adanya globalisasi telah membawa pengaruh yang besar bagi seluruh kegiatan ekonomi. Kondisi ini memaksa industri lebih cepat dalam mengambil keputusan, berani bertindak cepat, berani menanggung resiko dalam setiap keputusan dan selalu melakukan inovasi, proaktif dan strategis serta membina relasi demi meningkatkan kinerja pemasaran Abdul Manap (2016)[1]. Tentu saja industri yang mampu bertahan adalah yang memiliki sikap kewirausahaan menciptakanlingkungan pembelajaran yang bersumber dari eksplorasi dan eksperimen yangdiwujudkan dalam bentuk kreatifitas dan inovasi.

Keunggulan dalam persaingan dan pengakuan dari pelanggan secaraeksplisit telah menjadi bagian yang tidak terpisahkan (Weerawardena,2003,p.411). Inovasi sebagai sebuah manifestasi kreatifitas dan kapabilitaspemasaran yang tidak selamanya identik atau serta merta menghasilkan kinerja/pengakuan pelanggan yang optimal sudah tentu membutuhkan penelitian yanglebih mendalam.

Di dalam meningkatkan ekonomi rakyat, pengrajin keben perlu mendapat 


\section{JURNAL CAKRAWATI, Vol. 3 No. 1, Pebruari-Juli 2020 ISSN: 2620-5173}

perhatian, salah satunya adalah pengrajin keben di banjar Tanggahan Peken, Desa Sulahan Kecamatan Susut, Bangli. Mayoritas mata pencaharian penduduk di Banjar Tanggahan Peken sebagai pengrajin keben. Keben sebagai sarana upacara yang dipakai tempat banten umat Hindu kini sudah tidak lagi menjadi satusatunya sarana yang dipakai sebagai tempat upakara umat Hindu, kemajuan jaman dan teknologi memunculkan berbagai jenis keben yang terbuat dari bahan-bahan lain selain bambu, seperti penyalin, kayu atau fiber. Hal ini mengancam keberadaan pengrajin keben bambu untuk itu perlu dilakukan inovasi dalam pembuatan keben dari bahan bambu ini agar tidak tergerus oleh jaman. Keinovasian sangat berperan penting dalam orientasi kewirausahaan keben bambu ini. Hal ini menjadi petunjuk bagi pengrajin keben bambu untuk mengedepankan keinovasian dalam kegiatan usaha untuk mengutamakan kegiatan pengembangan desain produk yang khas dengan didasari kearifan lokal dan budaya religius yang kuat serta menghasilkan produk yang bervariasi dan diminati pelanggan. Permasalahanpermaalahan inilah yang menjadi dasar dalam penelitian ini, di mana penelitian ini akan menganalisis orientasi kewirausahaan yang berbasis kearifan lokal pada pengrajin keben Bambu di Banjar Tanggahan Peken, Desa Sulahan, Kecamatan Susut, Kabupaten Bangli.

Berdasarkan uraian latar belakang sebelumnya, penulis mengidentifikasi masalah yang diangkat dalam peneltian ini adalah:

1. Bagaimana perkembangan kinerja pemasaran pengrajin keben di Banjar Tanggahan peken saat ini?

2. Bagaimana penerapan orientasi kewirausahaan berbasis kearifan lokal pada kinerja pemasaran pengrajin keben di Banjar Tanggahan peken?

\section{METODOLOGI PENELITIAN}

Tempat peneliian ini di Banjar Tanggahan Peken, Desa Sulahan, Kecamatan Susut, Kabupaten Bangli, dengan mengambil salah satu usaha rakyat yaitu pengrajin keben bambu. Waktu penelitian ini dilakukan mulai bulan april sampai dengan Desember 2019.

Penelitian ini menggunakan jenis penelitian kualitatif. Sugiyono (2010 :15) megatakan bahwa peeelitian kualitatif adalah metode penelitian yang 


\section{JURNAL CAKRAWATI, Vol. 3 No. 1, Pebruari-Juli 2020 ISSN: 2620-5173}

berlandaskan pada filsafat postpositivisme digunakan untuk meneliti pada kondisi objek yang alamiah, peneliti sebagai instrumen kunci pengambilan sampel sumber data dilakukan secara purposive dan snowball, teknik pengumpulan dengan triangulasi, analisis data bersifat induktif/kualitatif, dan hasil penelitian kualitatif lebih menekankan makna dari pada generalisasi. Jenis pendekatan penelitian yang digunakan dalam penelitian ini adalah penelitian deskriftif kualitatif.

Berdasarkan pada data yang diperoleh, maka pembahasan dalam penelitian ini dilakukan dengan langkah-langkah sebagai berikut :

1) Studi Literatur

2) Melakukan pengumpulan data

3) Analisis dan perumusan masalah

4) Analisis orientasi kewirausahaan sesuai dengan nilai-nilai kearifan lokal pada masyarakat pengrajin keben di Banjar Tanggahan peken.

5) Perumusan Orientasi Kewirausahaan berbasis kearifan lokal

6) Penarikan Kesimpulan
Untuk dapat menjawab pertanyaan yang telah dimunculkan mengenai analisis orientasi kewirausahaan berbasis kearifan lokal untuk meningkatkan kinerja pemasaran, digunakan teknik untuk mengumpulkan datameliputi:

\section{Observasi}

Observasidilakukan sebagai tindakan awal untuk mempelajari permasalahan pengrajin keben bambu maka data yang diperoleh akan lebih lengkap dan tajam

\section{Studi Dokumentasi}

Dokumentasi adalah pengumpulan data atas dokumen berupa laporan dan catatan yang memberikan informasi terkait dengan orientasi kewirausahaan yang berbasis kearifan lokal pada pengrajin keben Bambu di Banjar Tanggahan Peken

\section{Wawancara}

Wawancaraadalah pengumpulan data dengan melakukan komunikasi langsung dengan pengrajin keben bambu di Banjar Tanggahan Peken sehingga dapat memperoleh tambahan data yang dapat 


\section{JURNAL CAKRAWATI, Vol. 3 No. 1, Pebruari-Juli 2020 ISSN: 2620-5173}

menggambarkan kinerja dan

permasalahan pemasarannya.

Setelah semua data terkumpul, selanjutnya dilakukan analisis datauntuk mendapatkan kesimpulan. Analisis data adalah proses menyusun data agar dapat ditafsirkan. Menyusun data bearti menggolongkan ke dalam pola, tema atau kategori tafsiran atau intrepetasi artinya memberikan makna kepada analisis, menjelaskan pola atau kategori, mencari hubungan antara berbagai konsep. Analisis data dilakukan melalui analisis kualitatif terhadap data bukan angka, dan analisis kuantitatif (statistik) terhadap data yang berupa angka. Adapun langkahlangkah analisis data dalam penelitian ini menggunakan analisis data model Miller dan Huberman ada tiga langkah yaitu, reduksi data, penyajian data dan kesimpulan (Suprayoga dan Tabroni, $2001 ; 193-195)$ :

\section{Reduksi data}

Reduksi data artinya sebagai proses pemilihan, pemusatan, perhatian dan penyederhanaan, pengabstrakan, transformasi data kasar yang muncul dari catatan-catatan lapangan

2. Penyajian data
Penyajian data adalah penyajian sekumpulan informasi yang tersusun serta memungkinkan adanya penarikan kesimpulan data dan pengambilan tindakan.

\section{Penarikan Kesimpulan}

Kegiatan selanjutnya adalah penarikan kesimpulan yang merupakan sebagian dari suatu kegiatan dari konfigurasi yang utuh.

Data yang sudah dianalisis selanjutnya disajikan dengan menggunakan metode informal, yaitu suatu metode penyajian data/perumusan data/hasil penelitian yang dideskripsikan dengan menggunakan kata-kata biasa, data yang telah terkumpul dalam penelitian ini diseleksi atau diklasifikasikan lebih dahulu. Data yang memiliki kehandalan dan reliabilitas terhadap permasalahan yang dikaji dimasukkan sebagai data pokok, sedang data yang relevansinya rendah tidak akan digunakan dalam menentukan hasil penelitian. Data formal yang menggambarkan kondisi subjek dan objek yang diteliti tentang orientasi kewirausahaan berbasis kearifan lokal, berupa tabel, bagan, dan foto-foto, berdasarkan hasil observasi wawancara 


\section{JURNAL CAKRAWATI, Vol. 3 No. 1, Pebruari-Juli 2020 ISSN: 2620-5173}

dan studi dokumentasi, dianalisis dan disajikan secara kualitatif dalam bentuk uraian.

\section{HASIL PENELITIAN}

Perkembangan Kinerja Pemasaran

Pengrajin Keben di Banjar Tanggahan Peken

Banjar Tanggahan Peken terletak di Desa Sulahan Kecamatan Susut Kabupaten Bangli. Batas wilayah dusun :

$\begin{array}{ll}\text { Sebelah Utara } & \text { : Ds Lumbuan } \\ \text { Sebelah Selatan } & \text { : Ds Penatahan } \\ \text { Sebelah Barat } & \text { : Ds Sulahan } \\ \text { Sebelah Timur } & \text { :DsTanggahan } \\ & \text { Gunung }\end{array}$

Jumlah penduduk 2.142 orang, penduduk laki-laki 1.072 orang, penduduk perempuan berjulah 1070 orang. Dari data yang diperoleh di banjar Tanggahan Peken mayoritas penduduk berprofesi sebagai pengrajin keben yaitu sebanyak 855 orang. Berdasarkan hasil wawancara dengan Kelian banjar dan beberapa pengrajin jumlah pengrajin di Banjar Tanggahan Peken mengalami penurunan, sekitar tahun 2015 hampir 90\% penduduk bermata pencaharian sebagai pengrajin keben namun jumlahnya menurun setiap tahun, saat ini kurang dari $50 \%$ penduduk berprofesi sebagai pengrajin.

Pelestarian usaha keben menjadi alasan pengrajin untuk tetap bertahan sampai saat ini.Keberadaan keben sebagai sarana upacara merupakan komitmen untuk melestarikan eksistensi keben sebagai warisan budaya di tengah maraknya persaingan usaha keben yang terbuat dari kayu ataupun fiber.

Profesi sebagai pengrajin keben merupakan pekerjaan turun-temunrun di Banjar tanggahan peken. Pekerjaan ini lebih banyak digeluti oleh wanita, dari yang muda hingga yang tua, terutama yang sudah menikah. Pada mulanya proses pemasaran keben hanya menunggu pesanan yang datang terutama pesanan dari pengepul yang berasal dari Luar Desa.

Kinerja pemasaran pengrajin keben di Banjar Tanggahan Keben dapat dilihat dari pertumbuhan pelanggan, pertumbuhan penjualan, porsi pasar dan kemampu labaan. Dalam Ferdinand (2006), untuk mengukur kinerja pemasaran terdiri dari empat indikator, diantaranya : 


\section{JURNAL CAKRAWATI, Vol. 3 No. 1, Pebruari-Juli 2020 ISSN: 2620-5173}

1. Pertumbuhan pelanggan merupakan tingkat perumbuhan pelanggan perusahaan porsi pasar

2. Pertumbuhan Penjualan merupakanderajat angka pertumbuhan volumepenjualan dalam tiga tahun terakhir

3. Porsi pasar merupakan besarnya kontribusi produk yang ditangani dapat menguasai pasar untuk produk sejenis dibandingkan industri bordir kebaya lainnya

4. Kemampu labaan merupakan besarnya keuntungan yang diperoleh oleh perusahaan.

Dari tahun ke tahun jumlah pelanggan usaha kerajinan keben di Banjar Tanggahan Peken mengalami pasang surut. Dari hasil wawancara dengan beberapa pengrajin menyebutkan bahwa pada hari-hari biasa jumlah penjualan tidaklah seberapa, namun pada saat harihari besar keagamaan Hindu maka penjualan semakin meningkat bahkan sampai lima kali lipat, tapi karena pembuatan keben yang memakan waktu lama membuat para pengrajin selalu kewalahan di hari raya. Konsumen keben di Banjar Tanggahan Peken berasal dari berbagai daerah Di Bali. Saat ini penjualan keben menyasar tak hanya di areal Bangli dan sekitarnya, tapi juga sudah dikirim hingga ke luar provinsi. Penjualan pun sudah menggunakan promosi melalui media sosial dan menggunakan jasa pengirimin.Keuntungan yang diperoleh pengrajin keben rata-rata $\operatorname{Rp} 400.000$ per minggunya. Keuntungan yang diperoleh oleh para pengepul keben di Banjar Tanggahan Peken rata-rata $\mathrm{Rp} 7.000 .000$ sampai Rp 10.000.000 perbulannya.

Untuk memperlancar penjualan keben di Banjar Tanggahan Peken dibentuk beberapa kelompok pengrajin. Saat ini ada sekitar delapan kelompok pengrajin yang tiap kelompok terdiri darii 15-25 orang. Tiap kelompok memiliki seorang pengepul yang membeli hasil kerajinan mereka. Selain itu para pengrajin juga ada yang menjual sendiri hasil keben mereka kepada konsumen melalui media online ataupun pemasaran langsung.

\section{Penerapan Orientasi}

\section{Kewirausahaan Berbasis Kearifan}

Lokal Pengrajin keben di Banjar

\section{Tanggahan Peken}

Kewirausahaan adalah faktor kunci dalam mendeterminasikan aktifitaspembangunan kapabilitas perusahaan. Orientasi kewirausahaan dari suatuperusahaan akan mendorong orientasi kompetitifnya (Merz 


\section{JURNAL CAKRAWATI, Vol. 3 No. 1, Pebruari-Juli 2020 ISSN: 2620-5173}

\& Suber, 1995).Kewirausahan juga merupakan elemen kunci dalam mendapatkan keunggulanbersaing yang tentu saja juga akan berakibat positif pada kinerja finansialnya.Perusahaan dengan kemampuan wirausaha yang tinggi akan sangatmemperhatikan inovasi, inisiasi perubahan, dan kecepatan respon yang tinggiuntuk terus berubah secara fleksibel (Naman \& Slevin, 1993).Porter (2008) mendefinisikan orientasikewirausahaan sebagai strategi benefit perusahaanuntuk dapat berkompetisi secara lebih efektif didalam market place yang sama. Suardika (2012) Mengingat pentingnya orientasi kewirausahaan dalam meraih keunggulan kompetitif dan kesuksesan usaha maka UKM perlu mengembangkan orientasi kewirausahaan dalam akivitas-aktivitas usahanya serta dijadikan landasan dalam perumusan dan penerapan strategi dalam berkompetisi. Adapun penerapan Orientasi kewirausahaan berbasis kearifan lokal di Banjar tanggahan Peken dilihat dari inovasi, sikap proaktif dan berani menanggung resiko.

\subsubsection{Inovasi}

Semakin berkembanganya jaman menuntut para pengrajin untuk terus berinovasi . inovasi berkelanjutan dalam perusahaan adalah persyaratan dasar untuk penciptaan keunggulan kompetitif. Inovasi dipandang sebagai mekanisme bagi perusahaan untuk beradaptasi dengan lingkungan yang dinamis (salman, 2015).

Inovasi yang dilakukan mayarakat pegrajin keben di Banjar Tanggahan Peken masi berbasis nilai-nilai kearifan lokal seperti

"Wiadin ririh enu liu peplajahan"

Ungkapan ini mengandung arti walaupun sudah pintar masih banyak yang harus dipelajari.

Ni luh ernawati, yang merupakan salah satu pengrajin keben mengatakan. "selalu belajar dalam membuat motif baru, kita pengerajinnya yang harus berinovasi agar bisa memenuhi pesanan, Karena permintaan konsumen semakin beragam jadi kita harus menambah ilmu dan teknik ngulat lagi,"

Nilai kearifan lokal pada penerapan inovasi juga dapat dilihat dari motif keben yang digunakan, yaitu motif matahari, motif swastika, motif bunga, motif catur dan banyak motif lainnya yang dipercaya memiliki makna tentang kesucian dan keagungan Tuhan.

\subsubsection{Proaktif}




\section{JURNAL CAKRAWATI, Vol. 3 No. 1, Pebruari-Juli 2020 ISSN: 2620-5173}

Proaktif sebagai tindakan mencari peluang pasar terus menerus dan eksperimen dengan menggunakan respon yang potensial terhadap kecenderungan perubahan lingkungan (Andriyani, 2006).

Para konsumen bisa memesan motif keben sesuai dengan keinginan mereka, sehingga konsumen merasa lebih puas, hanya saja untuk pemesanan motif memerlukan waktu pengerjaan yang lebih lama dari biasanyanya, yaitu sekitar 1 sampai 2 minggu.

Demi memenuhi kebutuhan konsumen, masyarakat banjar Tanggahan Peken menerapkan prinsip gilik saguluk, parasparo, salunglung sabayantaka, sarpana ya" adalah tata kehidupan yang mengutamakan kebersamaan, musyawarah mufakat,

kekeluargaan, kegotongroyongan, rasa senasib sepenanggungan, dan keharmonisan bersama. Sehingga dibentuklah kelompokkelompok pengrajin keben yang bekerja sama untuk membuat keben, sehingga pembuatan keben bisa dipercepat. Salah satunya adalah kelompok pengrajin keben Ibu Ni Nengah sujati yang terdiri dari delapan orang pengrajin, mereka membagi tugas masing-masing, ada yang bertugas dalam proses penyebitan (memotong dan menghaluskan bambu sesuai ukuran keben), proses pewarnaan dan proses menganyam. Selain ibu Nengah Sujati juga ada Ibu Wulan, Pemilik Wulan Bambu, beliau adalah pengrajin sekaligus pengepul kerajinan keben di banjar Tanggahan Peken, untuk memenuhi pesanan konsumen dengan tepat waktu, ibu Wulan juga memiliki beberapa pengrajin, selain berbagi rejeki, memiliki kelompok pengrajin juga membuat usaha Wulan Bambu semakin maju.

\section{Berani Menanggung Resiko}

Berani mengambil resiko, Menurut (Morris dan Kuratko, 2002) berani mengambil resiko (risk taking)menyangkut keinginan untuk meraih peluang yang kemungkinan dapat menyebabkan kerugian atau ketidaksesuaian kinerja yang signifikan.

Berani menanggung resiko tercermin dalam ungkapan bani meli bani ngadep"..Kalimat ini artinya adalahberani membeli berani menjual yang memiliki makna bahwa dalam menentukan harga barang atau jasa harus ada keadilandan tidak saling merugikan.

Para pengrajin keben di Banjar Tanggahan Peken, selalu menyediakan 


\section{JURNAL CAKRAWATI, Vol. 3 No. 1, Pebruari-Juli 2020 ISSN: 2620-5173}

keben dalam berbagai motif tanpa harus menunggu pesanan dari konsumen, sehingga ketika datang pesanan dalam jumlah banyak mereka bisa dengan cepat menangkap peluang tersebut, akan tetapi jika pesanan yang datang sedikit mereka siap menyimpan stok keben yang tersisa untuk di jual kembali.

\section{KESIMPULAN}

Berdasarkan hasil penelitian, maka dapat disimpulkan sebagai berikut :

1) perkembangan usaha kerajinan keben di desa tanggahandi lihat dari kinerja pemasaran, yaitu dari pertumbuhan pelanggan, pertumbuhan penjualan, porsi pasar, dan kemampulabaan. Usaha kerajinan keben merupakan usaha turun temurun untuk melestarikan kebudayaan.

2) Penerapan orientasi kewirausahaan berbasis kearifan lokal dapat meningkatkan kinerja pemasaran usaha kerajinan keben, hal ini menuntut para pengrajin lebih meningkatkan daya saingnya melalui penerapan inovasi berbasis kearifan lokal seperti ungkapan wiadin ririh enu liu peplajahan yang berarti setiap pengrajin tidak pernah pernah berhenti untuk belajar dan selalu melakukan inovasi untuk tetap dapat bersaing dengan produk keben lainnya, bersikap proaktif dan berani menanggung resiko tercermin dalam ungkapan bani meli bani ngadep".Kalimat ini artinya adalahberani membeli berani menjual yang memiliki makna bahwa dalammenentukan harga barang atau jasa harus ada keadilandan tidak saling merugikan.

\section{DAFTAR PUSTAKA}

Abdul Manap. 2016. Revolusi Manajemen Pemasaran.Bekasi ; Mitra Wacana Media

Alma, Buchori 2014.Manajemen Pemasaran dan Pemasaran Jasa.Bandung ; CV Alfabeta

Ariawati, ria ratna. 2004. Usaha Kecil dan Kesempatan Kerja.Unikom. Jakarta

Dharmawati, D.Made, 2016.Kewirausahaan. Jakarta ; PT Raja Grafindo Persada

Diah Ayu Septi Fauji, dkk, 2016. "Memaknai Etika Bisnis Berbasis Kearifan Lokal Pada Sentra Industri Tahu Kota Kediri Seminar Nasional Manajemen (SENIMA) 2016 - Universitas Negeri Surabaya

(UNESA)

Ferdinand, Augusty., 2003. "Sustainable Competitive Advantage : Sebuah Eksplorasi Model konseptual". Fakultas Ekonomi Universitas Diponegoro. Semarang. 
Gie, K.K. (1997). Ensiklopedi Ekonomi, Bisnis dan Manajemen. Jakarta; Delta Panangkal

$\begin{array}{lrr}\text { Hastuti,Rahmah. } & 2013 . & \text { Peluang } \\ \text { Kewirausahaan } & \text { dan } & \text { Faktor } \\ \text { Penghambat } & \text { UKMHandycraft } \\ \text { Berbahan Dasar } & \text { Kerang } & \text { (Studi } \\ \text { Kasus Pada UKM di } & \text { Bekasi). } \\ \text { Prosiding Seminar } & \text { Nasional } \\ \text { Kewirausahaan dan Inovasi Bisnis } \\ \text { III 2013, Universitas Tarumanegara. } \\ \text { Jakarta }\end{array}$

Indrawati, 2015. Metode Penelitian Manajemen dan Bisnis : Konvergensi Teknologi Komunikasi dan Informasi. Pt Refika Aditama: Bandung

Jauhari, Jaidan. 2010. Upaya Pengembangan Usaha Kecil dan Menengah (UKM) dengan memanfaatkan e-commerce. Jurnal Sistem Informasi (JSI) Vol.2. No.1 April 2010

Khairani Alawiyah Matondang, 2018 .Pengembangan Ekonomi Kreatif Berbasis Kearifan Lokal Besiang Air dalam Meningkatkan Pendapatan Penganyam (Studi Kasus di Kecamatan Sei Kepayang Barat).NIAGAWAN Vol 7 No 3 November 2018

Kotler, Philip. 2014. Manajemen Pemasaran.Edisi Bahasa Indonesia.Jakarta ;Penerbit Erlang 